\title{
THE
}

\section{The changing sources of polychlorinated dibenzo-p-dioxins and furans in sediments and the ecological risk for nekton in the lower Passaic River and Newark Bay, New Jersey, USA}

\author{
Mohammed Khairy \\ University of Rhode Island \\ Kirk Barrett \\ Rainer Lohmann \\ University of Rhode Island, rlohmann@uri.edu
}

Follow this and additional works at: https://digitalcommons.uri.edu/gsofacpubs

The University of Rhode Island Faculty have made this article openly available.

Please let us know how Open Access to this research benefits you.

This is a pre-publication author manuscript of the final, published article.

Terms of Use

This article is made available under the terms and conditions applicable towards Open Access Policy Articles, as set forth in our Terms of Use.

\section{Citation/Publisher Attribution}

Mohammed Khairy, Kirk Barrett, Rainer Lohmann. (2015). "The changing sources of polychlorinated dibenzo-p-dioxins and furans in sediments and the ecological risk for nekton in the lower Passaic River and Newark Bay, New Jersey, USA." Environmental Toxicology and Chemistry. Available at: http://onlinelibrary.wiley.com/doi/10.1002/etc.3223/abstract

This Article is brought to you for free and open access by the Graduate School of Oceanography at DigitalCommons@URI. It has been accepted for inclusion in Graduate School of Oceanography Faculty Publications by an authorized administrator of DigitalCommons@URI. For more information, please contact digitalcommons-group@uri.edu. 


\section{Running Title \\ Sources and risk of PCDD/Fs in Passaic River sediment}

\section{Rainer Lohmann}

Graduate School of Oceanography, University of Rhode Island, Narragansett, Rhode Island 02882, United States

E-mail address: rlohmann@uri.edu

Phone: 401-874-6612

Fax 401-874-6811 
The changing sources of polychlorinated dibenzo-p-dioxins and furans in sediments and the ecological risk for nekton in the lower Passaic River and Newark Bay, New

$$
\text { Jersey, USA }
$$

\footnotetext{
Mohammed Khairy ${ }^{\dagger \dagger}$, Kirk Barrett ${ }^{\S}$, Rainer Lohmann ${ }^{* \dagger}$

${ }^{\dagger}$ Graduate School of Oceanography, University of Rhode Island, Narragansett, Rhode Island 02882, United States

"Department of Environmental Sciences, Faculty of Science, Alexandria University, 21511 Moharam Bek, Alexandria, Egypt

${ }^{\S}$ Department of Environmental and Civil Engineering, Manhattan College, Riverdale, New York 10471, United States
} 
Corresponding author e-mail address: rlohmann@uri.edu 


\begin{abstract}
Polychlorinated dibenzo- $p$-dioxins and dibenzofurans (PCDD/Fs) were measured in sediments (surface and deeper sediments) and porewater of the lower Passaic River and Newark Bay (NJ, USA) to apportion their sources and conduct an ecological risk assessment. Positive matrix factorization (PMF) was applied to identify sources of PCDD/Fs. Five source profiles were extracted from the PMF model applied to the sediment samples including chloranil, combustion, polychlorinated biphenyl impurities, mixed urban sources and the historical contamination from the former Diamond Alkali plant (DAP). The ecological risk assessment was estimated using several lines of evidence depending on site specific data (blue crab and fish samples representing different feeding habits and positions in the trophic wood web of the river). Porewater concentrations gave the best estimates of lipid concentrations especially in the blue crab samples (with an average factor difference of 3.8). Calculated hazard quotients (HQ) for the fish samples and blue crab were $>1$ based on the no-effect concentration and tissue screening concentration approaches. At the same time, calculated porewater toxic units were $>1$ and sediment concentrations exceeded the published sediment quality guidelines for the protection of fish and benthic species indicating the existence of significant risk to the aquatic life in the Passaic River. Accordingly, further actions and control measures are needed to reduce the emission of $\mathrm{PCDD} / \mathrm{Fs}$ from ongoing sources.
\end{abstract}

Keywords: PCDD/Fs; Passaic River; Positive matrix factorization; Ecological risk assessment 


\section{INTRODUCTION}

In metropolitan areas, the environmental quality of waterways becomes greatly influenced by the degree of urbanization and industrialization occurring in the region. A key example on such influence in USA is the lower Passaic River (Figure 1), a tributary of the New York/New Jersey Harbor estuary complex, extending from the head-of-tide at Dundee Dam (river km 29) to its mouth at Newark Bay, New Jersey, USA (river km 0). The river is part of a highly urbanized ecosystem that has been severely degraded by more than 200 years of urbanization and industrialization [1]. As a consequence, elevated concentrations of polychlorinated dibenzo-p-dioxins and furans (PCDD/Fs) including the highly toxic 2,3,7,8-TCDD congener, polycyclic aromatic hydrocarbons (PAHs), polychlorinated biphenyls (PCBs), chlorinated pesticides, chlorinated herbicides, and heavy metals were detected in sediments, water, and biota collected the Lower Passaic $[2]$.

The Passaic River has been identified as one of the worst dioxin pollution cases in USA [3]. The primary source of dioxin was the former Diamond Alkali pesticide (DAP) manufacturing facility (river km 5.0, Fig. 1) at 80 Lister Avenue in Newark, NJ, which operated from 1948 to 1969 . The facility produced DDT and sodium 2,4,5trichlorophenate, which was then used to synthesize 2,4,5-trichlorophenoxyacetic acid (2,4,5-T). Dioxins, especially 2,3,7,8 -TCDD, were generated as an unwanted by-product of this process [3]. Dioxins emitted from this facility resulted in the contamination of adjacent areas such as Newark Bay. It has been estimated that 4 to $8 \mathrm{~kg}$ of 2,3,7,8-TCDD may have been transported from the Passaic hotspot downstream into Newark Bay over a period of $(\sim) 40$ years, from 1948 to 1985 [4]. Due to the high sedimentary 
concentrations of PCDD/Fs, this site was added to the USEPA Superfund list in 1984 and is currently undergoing a two-phase remediation effort to remove $153,000 \mathrm{~m}^{3}$ of sediment via dredging [5]. The Superfund program recently proposed extending remedial dredging to the entire lower $13 \mathrm{~km}$ of the Passaic River [5].

Previous studies indicated a decline over time in the sediment concentrations of PCDD/Fs collected from the Passaic River and adjacent areas [6]. Yet, marine organisms collected from the Passaic and nearby locations have continued to exhibit high PCDD/Fs body burdens $[2,7]$. Contamination of fish with PCDD/Fs, metals, and other organic pollutants prompted the NJ Department of Environmental Protection (NJDEP) (www.FishSmartEatSmartNJ.org; www.state.nj.us/dep/dsr/crab-outreach/alertenglish.htm ) to issue fish, shellfish, and blue crab consumption bans for all of the lower Passaic River and estuary. Recently, Khairy et al. [2] indicated that the accumulation of hydrophobic organic compounds (including PCDD/Fs) in fish and blue crab samples collected from the Passaic River and Newark Bay occur from sediments, porewater and diet. This suggests that PCDD/Fs in sediments of the Passaic River continue to be available for bioaccumulation. A major question is whether PCDD/Fs in the Passaic River is solely the result of the historical contamination (from the Diamond Alkali Plant) or whether there are other ongoing sources of PCDD/Fs into the Passaic River and, if so, what are their relative contributions.

PCDD/Fs can be emitted from a number of activities, including industrial processes, smelting operations, pesticide manufacturing, combustion on small and large scale, automobile exhaust, landfills, sewage treatment plants and natural events such as 
forest fires [3]. Most of these activities can be located in the highly urbanized and industrialized area surrounding the Passaic River. Accordingly, it is important to identify the ongoing sources of dioxins in the region, which can inform the measures taken by policy makers to decrease dioxin pollution in the Lower Passaic River.

Receptor models apply statistical methods to identify emission sources based on pollution fingerprints and quantify their contributions [8]. Varying receptor modeling techniques have been developed in the last decades. Among them are the multivariate models and chemical mass balance model wherein the latter is the method of choice when the impacting sources and their profiles have been predetermined [9]. Multivariate models such as principle component analysis (PCA), Unmix model and positive matrix factorization model (PMF) have been frequently used and proved to be useful tools in source apportionments studies in air pollution studies without prior knowledge of source profiles or source characteristics (Khairy and Lohmann [10] and references therein). Receptor modeling applications have then expanded to apportion sources of pollutants in sediments $[8,11,12]$ and references therein).

PCA has been widely used to apportion the sources of PCDD/Fs in sediments [1319]. In contrast, PMF was rarely applied [8, 20, 21]. One advantage of applying PMF is its ability to solve the problem of negative factor loadings/scores by integrating nonnegativity constrained factor analysis, making factor loadings and scores more interpretable.

In previous studies, recent sources of PCDD/Fs in surface sediments sampled from Newark Bay and the Passaic River were identified using PCA and polytopic vector 
analysis [22-25]. Pulp and paper mills effluents, pentachlorophenol, PCB Aroclor mixtures, combustion processes, municipal sewage and wastewater treatment plants were identified as major sources. However, these studies were performed more than two decades ago and the continuous improvement in the pollution control measures by the governmental agencies in all the industrial sectors and incinerators could result in different sources and contributions.

In the present study, surficial sediment samples were collected from the Lower Passaic River and Newark Bay to: (i) investigate the concentrations and spatial distribution of $\mathrm{PCDD} / \mathrm{Fs}$, (ii) apportion the sources of $\mathrm{PCDD} / \mathrm{Fs}$ and to determine the relative importance of the extracted sources using PMF model; and (iii) asses the ecological risk of PCDD/Fs.

\section{MATERIALS AND METHODS}

Sampling of sediments, biota, river water and porewater

Twenty two surficial sediment samples were collected during SeptemberNovember 2011 at 22 locations identified in Figure 1 from the lower Passaic River (river $\mathrm{km} 29.6$ to river $\mathrm{km} 0$ ) and Newark Bay. All sediment samples except two were collected from mudflats at low tide. A glass jar (previously washed with soap and water

and baked at $450{ }^{\circ} \mathrm{C}$ for 4 hours) was filled by scooping mud by hand using a shovel. At two sites, labeled NB1 and km 5.4, samples were collected from a small boat using a hand-held dredge through about $60 \mathrm{~cm}$ of water. The material from the dredge was immediately transferred to a jar, kept in an ice box and shipped frozen to our lab. Samples were then kept in a freezer at $-20{ }^{\circ} \mathrm{C}$ for three months until extraction and 
analysis. Detailed description of the biota sampling can be found in Khairy et al. [2]. Briefly, 350 finfish specimens representing 10 species from different trophic positions and feeding strategies. Feeding strategies were classified as "benthic", "bentho-pelagic", and "pelagic" based on feeding position in the water column according to recorded stable isotopic data.

For the sampling of river water, passive low density polyethylene (LDPE) samplers were deployed at six different locations along the lower Passaic River fastened to an anchored rope and suspended in water $\sim 1-2 \mathrm{~m}$ below the surface.

Direct measurement of the freely dissolved fraction of PCDD/Fs in the porewater was performed using LDPE (PE-water tumbling experiment) according to the method previously optimized in our group [6].

\section{Extraction and chemical analysis}

Before analysis, sediments were oven dried and at $35^{\circ} \mathrm{C}$ for one week, and then ground. Extraction and cleanup of the sediment samples was performed according to the USEPA method 1613 with some modifications [2]. Briefly, $10 \mathrm{~g}$ (dry weight) of each sample were loaded into a precleaned thimble, spiked with $10 \mu$ of a surrogate standard mixture (in nonane) composed of labeled PCDDs $\left({ }^{13} \mathrm{C}_{12}\right.$ 2,7-DiCDD, 2,3,7,8-TCDD, 1,2,3,6,7,8-HxCDD, 1,2,3,4,6,7,8,9-CDD; $2.5 \mathrm{ng} / \mu \mathrm{L})$ and Soxhlet extracted with dichloromethane (DCM) for $48 \mathrm{~h}$. Extracts were then evaporated in a turbovap, solvent exchanged to hexane, and further concentrated to $1 \mathrm{~mL}$ under a gentle stream of nitrogen. Extracts were purified over multilayer silica column according to method 1613. 
PCDD/Fs were eluted with $150 \mathrm{~mL} n$-hexane/DCM (70:30). After concentrations and solvent exchange to $n$-hexane, extracts were passed through an activated carbon column (0.8 $\mathrm{cm}$ i.d filled with $2 \mathrm{~cm}$ activated carbon/celite mixture) that was preconditioned with toluene, DCM/cyclohexane (1:1, v:v) and $n$-hexane. The column was eluted with $5 \mathrm{ml}$ DCM/cyclohexane (1:1, v:v; F1). Mono- and di-chlorinated dioxins and furans were eluted in this fraction. The column was then turned over, and all the other PCDD/Fs were eluted with $45 \mathrm{~mL}$ of toluene (F2). Toluene extracts were then concentrated to $0.5 \mathrm{~mL}$ in the Turbovap at $45^{\circ} \mathrm{C}$ and 5 psi. Samples were further concentrated to $(\sim) 25 \mu \mathrm{L}$ by gently blowing with ultrahigh purity $\mathrm{N}_{2}$ gas ( $\left.\sim 1 \mathrm{psi}\right) . d 14$ - $p$-terphenyl was added as an injection standard ( $25 \mu \mathrm{L}$ of $100 \mathrm{pg} / \mu \mathrm{L}$ solution) and the final volume was $(\sim) 25 \mu \mathrm{L}$. Detailed extraction and cleanup of the biota samples can be found in Khairy et al. [2]. For $\mathrm{PCDD} / \mathrm{Fs}$ analysis in LDPE (for river water and porewater), extracts were passed over an activated carbon column using USEPA method with some modifications [2].

Eleven PCDD congeners including 2-CDD, 2,7-DiCDD, 2,8-DiCDD, 2,3,7TriCDD, and the 2,3,7,8- substituted toxic congeners (2,3,7,8-TCDD, 1,2,3,7,8-PeCDD, 1,2,3,4,7,8-HxCDD, 1,2,3,6,7,8-HxCDD, 1,2,3,7,8,9-HxCDD, 1,2,3,4,6,7,8-HpCDD and $1,2,3,4,6,7,8,9-\mathrm{CDD})$ were analyzed in the present study in addition to 9 PCDF congeners including 2-CDF, 2,8-DiCDF, 2,4,8-TriCDF, 2,3,7,8-TCDF, 1,2,3,7,8-PeCDF, 2,3,4,7,8PeCDF, 1,2,3,4,7,8-HxCDF, 1,2,3,4,6,7,8-HpCDF and 1,2,3,4,6,7,8,9-CDF. PCDD/Fs were analyzed using an Agilent GC 6890N with a DB-5 MS fused silica capillary column (30 $\mathrm{m} \times 0.25 \mathrm{~mm}$ i.d., $0.25 \mu \mathrm{m}$ film thickness, J\&W Scientific) equipped with a Quattro micro GC tandem MS (Waters) according to the method detailed in [2]. 2,7/2,8-DiCDD 
were not chromatographically separated and reported concentrations represent the sum of both congeners.

\section{Quality assurance}

Procedural blanks, matrix spikes, duplicate samples (20\% of the total samples) and a certified reference material (SRM 1944 New York/New Jersey waterways sediments) were included with each sample batch and were carried throughout the entire analytical procedure in a manner identical to the samples. Recoveries of the surrogate standards generally ranged from 65 to $101 \%$. Matrix spikes recoveries were always $>90$ $\%$ and $<110 \%$ with relative standard deviation $<20 \%$. Recoveries of PCDD/Fs in the $\operatorname{SRM}(n=4)$ ranged from $96 \pm 2 \%$ to $102 \pm 3 \%$. Results of the replicate analysis indicated that the reproducibility of the analysis ranged from 5.8-14.6\%. Calculated concentrations of PCDD/Fs were reported as less than the limit of detection (LOD) if either the observed isotope ratio was not within $20 \%$ of the theoretical ratio or the peak area was not greater than the specified threshold (3 times the noise). LOD ranged from $1.2 \mathrm{pg} / \mathrm{g} \mathrm{dw}(2,3,7-T r i C D D)$ to $8.0 \mathrm{pg} / \mathrm{g} \mathrm{dw}(1,2,3,4,6,7,8,9-\mathrm{CDD})$.

Positive Matrix Factorization (PMF).

PMF is a receptor model, which is a mathematical approach for quantifying the contribution of sources to samples based on the composition or fingerprints of the sources assuming that a measured dataset conforms to a mass-balance of a number of constant source profiles contributing varying concentrations over the time of dataset. 
PMF has the following advantages over PCA: (i) the uncertainty-weighting of each data point entered into the model; (ii) non-negative constraint and (iii) extracted factors in PMF are not orthogonal to each other [26].

PMF is a multivariate factor analysis tool that decomposes a matrix $(\mathrm{X})$ of speciated sample data into two matrices: factor contributions $(G=n \times p)$ and factor profiles $(F=m \times p)$, where $n$ and $m$ are the number of samples and species respectively entered into the model and $\mathrm{p}$ is the selected number of factors (Eqn. 1):

$$
\mathrm{X}=\mathrm{GF}+\mathrm{E}
$$

where $\mathrm{E}$ is the residual that can be expressed as (Eqn. 2):

$$
\mathrm{E}_{\mathrm{ij}}=\mathrm{X}_{\mathrm{ij}}-\sum_{k=1}^{p} G_{i k} \cdot F_{k j}
$$

Factor contributions and profiles are derived by the PMF model minimizing the objective function $Q$ (Eqn. 3):

$$
\mathrm{Q}_{\mathrm{ij}}=\sum_{i=1}^{n} \sum_{\mathrm{j}=1}^{\mathrm{m}}\left[\frac{X_{i k}-\sum_{k=1}^{p} G_{i k} F_{k j}}{u_{i j}}\right]^{2}
$$

where $\mathrm{u}$ is the uncertainty in $\mathrm{X}$. Equation 3 is solved by the PMF model. In the present study, the newest version of the USEPA PMF model (Version 5.0, 2014) was used.

PMF allows for the check of random errors, rotational ambiguity on the output results by running three types of analysis: bootstrap (BS) analysis (to check for random 
errors), displacement (DISP) analysis (check the effects of rotational ambiguity) and BSDISP hybrid approach. In the present study, the three tests were performed and the recommendations given in the PMF user guide were followed (http://www.epa.gov/heasd/documents/PMF_5.0_User_Guide.pdf).

Data preparation: The model was run with a data matrix composed of the 22 newly collected surficial sediment samples and seven depth intervals from two previously analyzed sediment cores collected from the lower River (at river km 5.0) and Newark Bay (at site NB1 in Fig. 1) [6]. The depth intervals corresponded to years 1941, 1954, 1977 and 2002 in Newark Bay and 1976, 1991 and 2007 in the Passaic River as determined in [7]. The data matrix was composed of 29 samples x $19 \mathrm{PCDD} / \mathrm{F}$ congeners (2.7/2.8-DiCDD were not chromatographically resolved and they were both entered in the matrix as one congener). Half the LOD was used when a concentration was below the LOD. The uncertainty was calculated for each variable according to [27], and entered into the model.

Selection of the number of sources and diagnostic tools: To determine the optimal number of sources, the PMF model was run 100 times requesting 2-8 factors, and each run was initialized with different starting points, i.e. changing the seed value, in order to ensure that the program identified a global (not local) minimum of $Q$, the objective function. In addition, extra modeling uncertainty $(10 \%)$ was imposed to account for changes in the source profiles and other sources of variability. For selecting the optimum number of sources, the following were considered: (i) number of sources that provided clear, physically meaningful results while reducing matrix dimensionality; (ii) 
comparison between the theoretical and true $\mathrm{Q}$ values (should be equal); (iii) coefficient of determination (COD) comparing observed vs predicted concentrations of the entered congeners; and (iv) scaled residuals of the model (below 4.0). Afterwards, 100 bootstrap runs were conducted with minimum correlation R-value of 0.6 to examine the stability and estimate the uncertainty of the base run solution. All of the bootstrapped factors were matched with a factor from the base solution.

Identification of the resolved sources: To identify the resolved factors, spatial variation of the factor scores and comparison of congener patterns with known sources were considered. The cosine theta similarity metric was used for the congener pattern matching [28]. Source profiles obtained from the PMF model were compared to 45 different profiles of PCDD/Fs obtained from the United States source inventory of dioxins including vehicle emissions (diesel and gasoline), incineration (municipal solid wastes, hazardous wastes, medical wastes, sewage sludge, household wastes, coal combustion, wood combustion, oil combustion), forest fires, sewage sludge, wastewater effluents, pulp and paper mills, primary and secondary smelters, chlorine production, technical pentachlorophenol, PCB Aroclor mixtures, landfills, landfill gas flaring, 2,4,5trichlorophenoxy acetic acid, chloranil and pigments/dyes [29] (Supplemental Data, Table S1). PCDD/Fs profiles in the urban dust's certified reference material (SRM 1649b) was also included. Profiles were rescaled to match the congeners measured in the present study.

Ecological risk assessment of $P C D D / F$ s 
In the present study, the risk assessment was performed according to the framework of the USEPA [30] for both fish and benthic species. The predicted exposure concentration (PEC) was either the detected tissue concentrations in the fish species or the sediment and porewater concentrations (for benthic species). Additionally, we estimated the uptake of PCDD/Fs from each sorbent phase including sediments [organic carbon $(\mathrm{OC})$, organic carbon + black carbon $(\mathrm{OC}+\mathrm{BC})]$, porewater (bioavailable fraction of sediments) and the river water to determine the possible uptake sources of PCDD/Fs in the Passaic River. Several approaches including no effect tissue concentration and tissue screening concentrations (for fish) and sediment quality guidelines, equilibrium partitioning sediment quality benchmark and porewater toxic unit (for benthic species) were used to determine the predicted no effect concentration (PNEC). All quality guidelines used in the present study are given in Table 1 [31-37]. Finally, risk characterization was done using the hazard quotient approach (HQ) by comparing PEC to PNEC (see Supplemental Data for more details on the methodology applied). It is important to note that all the water quality standards used in the present study were determined based on the conventional active sampling technique (total dissolved concentration), which are expected to be higher than the freely dissolved concentrations determined in the present study using the passive sampling technique.

\section{RESULTS AND DISCUSSION}

\section{Spatial distribution of $P C D D / F s$}

Concentrations of $\sum_{20}$ PCDD/Fs ranged from $330 \mathrm{pg} / \mathrm{g} \mathrm{dw}$ (above Dundee Dam) to $6,400 \mathrm{pg} / \mathrm{g} \mathrm{dw}$ ( $\mathrm{km} 5.0$ at the Superfund site) with an average concentration of 1,970 $\mathrm{pg} / \mathrm{g} \mathrm{dw}$ (Figure 2). Concentrations of tetra- through octa-chlorinated dioxins and furans 
in the present study were lower than concentrations previously detected in sediments from Lake Shinji, Japan (8,600 pg/g dw [15]), Housatonic River, Massachusetts (160 $82,000 \mathrm{pg} / \mathrm{g} \mathrm{dw}$ [38]), rivers in the United Kingdom (450 - 9,300 pg/g dw [39]), Tokyo Bay, Japan (3,150 - 20,000 pg/g dw [40]), Venice Lagoon, Italy (65 - 140,000 [41]), Willamette Basin, Oregon (100 - 50,000 pg/g dw [18]), Baltic Sea $(<250-210,000$ pg/g $\mathrm{dw}$ [42]), and previously detected PCDD/Fs concentrations in sediments of the Passaic River and Newark Bay in 1990 (330 - 19,200 pg/g dw [23]), 1991-1993 (140 - 211,000 $\mathrm{pg} / \mathrm{g} \mathrm{dw}$ [22]), $2006(1.3-56000 \mathrm{pg} / \mathrm{g} \mathrm{dw}$ [43]) and in sediment cores collected from the Superfund site and Newark Bay [6]. Concentrations of 2,3,7,8-TCDD detected at the area surrounding the Superfund site $(70-220 \mathrm{pg} / \mathrm{g} \mathrm{dw})$ were lower that concentrations detected in the uppermost intervals of high resolution cores collected in 2011 (418 - 776 $\mathrm{pg} / \mathrm{g} \mathrm{dw}$ ) [44]. On the other hand, detected PCDD/F concentrations in the present study were higher than concentrations observed in Hyeongsan River, Korea (4.8 - 1,600 pg/g $\mathrm{dw}$ [45]) and in Detroit and Rouge Rivers, Michigan (70 - 1,400 pg/g dw ).

Higher PCDD/F concentrations in surficial sediments were generally observed in the region from km 13.8 to km 3.7 and in Newark Bay at the mouth of the Passaic River compared to the other sites (Figure 2). The maximum detected concentrations of tetrathrough octa-chlorinated dioxin congeners were always observed in the portion from river $\mathrm{km} 5.4$ to river km 3.7 (Figure 2A), near the DAP site. A distinctive pattern was observed for 2,3,7,8-TCDD and 1,2,3,4,6,7,8,9-CDD (OCDD), where concentrations generally increased from river km 29.6 (above Dundee Dam) to river km 5 (DAP site); concentrations then decreased from river $\mathrm{km} 5$ to river $\mathrm{km} 0$ at Newark Bay (Supplemental Data, Figure S1A), except for site NB1. The spatial distribution of PCDF 
congeners showed more variability compared to PCDDs (Supplemental Data, Figure S1B). Moving average calculations indicated that $1,2,3,7,8-\mathrm{PeCDF}, 1,2,3,4,7,8-\mathrm{HxCDF}$ and 1,2,3,4,6,7,8-HpCDF had similar spatial patterns as PCDDs. Concentrations of 2,3,7,8-TCDF and 1,2,3,4,6,7,8,9-CDF (OCDF) showed a close pattern to their corresponding PCDD congeners except that maximum concentrations were observed at river km 8.8 (compared to 5.0 for PCDDs). 2,3,4,7,8-PeCDF showed a different pattern compared to the other congeners (Figure S1B), where elevated concentrations were observed at river kms 10.6, 8.8, 5.0 and 3.7 compared to the other locations.

The pattern observed for 2,3,7,8-TCDD is as described earlier [4, 44]: sediments at the Superfund site are still the major source of 2,3,7,8-TCDD to the river and Newark Bay. Although this contamination happened decades ago (i.e., an aged source), it is still reflected in the river not only at the site of the former DAP, but 2,3,7,8-TCDD spread upriver until approximately river km 12.8 and downriver towards Newark Bay.

Surprisingly, most of the investigated PCDD/F congeners showed elevated concentrations at the Superfund site and surrounding areas (river kms 5.4-3.7). We assume that this pattern is not related to the historic DAP contamination source but to the current existing sources of $\mathrm{PCDD} / \mathrm{Fs}$ in the region (see below).

As shown in Figure 2A, OCDD was the dominant congener detected in surficial sediments of the Passaic River. It comprised, on average, $43 \%$ of total PCDD/F concentrations followed by OCDF (10 \%), 1,2,3,4,6,7,8-HpCDF (10 \%), 1,2,3,4,6,7,8HpCDD (8.0 \%) and 2,3,7,8-TCDD (4.0 \%). Similarly, Newark Bay sediments were dominated by OCDD (40 \%) and OCDF (18\%). However, 1,2,3,4,6,7,8-HpCDD and 
2,3,7,8-TCDD showed only minor contributions $(<4.0 \%)$ in Newark Bay except at NB1. Instead, the lower chlorinated congeners (2,7/2,8-DiCDD and 2,4,8-TriCDF) showed significant contribution in sediments of Newark Bay (11\% and $4.0 \%$ respectively). This implies that Newark Bay (especially in regions away from the influence of the Passaic River) is affected by different, possibly current PCDD/F sources [46].

Relative abundance of PCDD/F congeners in sediments of the present study were compared with those observed in sediments collected by the Contamination Assessment and Reduction Project (CARP) (Supplemental Data, Figure S2) [43] and those presented in the recent study by Quadrini et al. [44] (Supplemental Data, Figure S3). As shown in Figure S2, good agreement is observed between the profiles in the two studies, where the higher chlorinated PCDD/F congeners dominated the sedimentary profiles (see supplemental data for more details).

In terms of the World Health Organisation's Toxic Equivalents (TEQ, Figure 2B), PCDD/F concentrations ranged from $4.0 \mathrm{pg}$ TEQ/g dw (river km 29.6 above Dundee Dam) to $410 \mathrm{pg}$ TEQ/g dw with an average concentration of $135 \mathrm{pg}$ TEQ/g dw. Among all detected PCDD/F congeners, 2,3,7,8-TCDD dominated total WHO-TEQ (contribution of $71 \pm 17 \%$ ) in all the samples (except those above Dundee Dam) followed by $1,2,3,7,8$ $\operatorname{PeCDD}(12 \pm 8.0 \%), 2,3,4,7,8-\operatorname{PeCDF}(5.0 \pm 10 \%), 2,3,7,8-\mathrm{TCDF}$ and $1,2,3,4,7,8-$ $\operatorname{HxCDF}(3.0 \pm 2.0 \%$ each $)$, and 1,2,3,7,8,9-HxCDD $(2.0 \pm 1.0 \%)$

\section{Source factors of $P C D D /$ Fs in surficial sediments}

Five source profiles were extracted from the PMF model. Mono- through trichlorinated congeners were down weighted to 'bad' due to their poor reproducibility by 
the model $(\mathrm{COD}<0.2)$. Concentrations of all the other congeners were successfully reproduced by the model with good COD values (Supplemental Data, Table S2). Factor loading profiles for PCDD/Fs in superficial sediments are shown in Figure 3, along with the literature profile [29] of the most closely matching source. Literature profiles of PCDD/Fs in the different sources used for comparison are given in Table S1.

The first factor was responsible for $13 \%$ of the mass of PCDD/Fs with high loading on 2,3,7,8-TCDD (94 \% of the congener is loaded on this factor) and low loadings on 1,2,3,4,6,7,8-HpCDD, OCDD, 2,3,7,8-TCDF, 1,2,3,4,7,8-HxCDF, 1,2,3,4,6,7,8-HpCDD and OCDF (Figure 3A). This factor's profile did not match any of the literature source profiles. However, the high contribution from 2,3,7,8-TCDD indicates the signature of historical contamination from the Diamond Alkali Plant (DAP) which was located at approximately river km 5 (Figure 1) [4]. Accordingly, the historical contamination from the DAP is still the main source of $2,3,7,8$-TCDD (94 \%) in the region, similar to the conclusion reached by Quadrini et al. [47].

Factor 2 (Figure 3B) was responsible for $41 \%$ of the total mass of PCDD/Fs with high loadings on OCDD and moderate loadings on 1,2,3,4,6,7,8,9-HpCDF, 1,2,3,4,6,7,8$\mathrm{HpCDF}$ and 1,2,3,4,6,7,8-HpCDD. This factor showed the highest similarities with profiles of PCDD/Fs in technical pentachlorophenol (PCP; $\operatorname{Cos} \theta=0.99)[13-15,29,48$ 50] and atmospheric deposition of urban dust $(\operatorname{Cos} \theta=0.98)$ [48]. All the sources that had close similarities with this source factor are related to urban activities. Accordingly, we selected this factor to represent mixed urban sources. 
Factor 3 was responsible for $13 \%$ of the total mass of PCDD/Fs and had heavy loadings on 1,2,3,4,6,7,8-HpCDF, OCDF and OCDD (Figure 3C). This factor showed the highest similarity $(\operatorname{Cos} \theta=0.93-0.99)$ with profiles of PCDD/Fs measured in chloranil [29]. In the study performed by Rodenburg et al. [28] to apportion the sources of PCBs in the New York/New Jersey Harbor, they indicated that pigments that are discharged with wastewater and combined sewer overflow (CSO) are considered a source of PCBs (PCB 11) and that this source is prevailing in the Passaic River and Newark Bay. Additionally, Ehrlich et al. [22] and Barabas et al. [25] found the signature of chloranil in sediments of the lower Passaic River. We therefore assume that this source is related to effluents of wastewater and CSO in the region.

Factor 4 was responsible for $8.0 \%$ of the total mass of PCDD/Fs and had heavy loadings on 2,3,7,8-TCDF and 2,3,4,7,8-PeCDF, moderate loadings on 1,2,3,7,8-PeCDF and almost no loadings on PCDDs (Figure 3D). This factor showed the highest similarity with profiles of PCDD/Fs impurities in technical PCB Aroclor mixtures [29].

Factor 5 was responsible for $25 \%$ of the total mass of PCDD/Fs and had heavy loadings on OCDD, moderate loadings on OCDF, 1,2,3,4,6,7,8-HpCDD/F and low loadings on the remaining PCDD/F congeners (Figure 3E). This observed pattern had close similarities with thermal processes (municipal solid waste incineration: $\operatorname{Cos} \theta=$ $0.92-0.99$ [29]; wood combustion: $\operatorname{Cos} \theta=0.98$ [29]; coal combustion: $\operatorname{Cos} \theta=0.92$ [29]; secondary smelters: $\operatorname{Cos} \theta=0.89$ [29]; emissions from vehicles with catalytic converters using unleaded gasoline $(\operatorname{Cos} \theta=0.98)$ [29] and vehicle emissions in general 
$[49,51,52])$. Accordingly, this source factor was selected to probably represent PCDD/Fs emitted from combustion.

Source apportionment of PCDD/Fs in surficial sediments of the Lower Passaic River

Normalized contributions of the PMF source factors and their spatial distribution in sediments are shown for each sampling site in Figures 1 and Supplemental Data, S4 respectively. Based on average probable source contributions, the following descending order was observed in surficial sediments of the lower Passaic River: mixed urban sources that are mainly related to OCDD $(43 \%)>$ combustion $(34 \%)>$ chloranil $(13 \%)$ $>$ PCBs $(10 \%$ each $)>$ Diamond Alkali Plant $(8.0 \%)$. Mixed urban sources were found to be the major source of PCDD/Fs in surficial sediments in the river segment from $\mathrm{km} 29.6$ (above Dundee Dam) to $\mathrm{km} 16$ and from $\mathrm{km} 11.2$ to $\mathrm{km} 10.6$ comprising on average 80 $\%$ and $50 \%$ respectively of the total sediment concentrations. This is due to the dominance of the higher chlorinated dioxins/furans at these sites. Contributions from the probable mixed urban source category generally decreased linearly from river km 29.6 to river $\mathrm{km} 0.6\left(\mathrm{R}^{2}=0.72, \mathrm{p}<0.001\right)$, where other sources started to show significant contributions (Figure S4). In contrast, contributions from the combustion source category increased linearly $\left(\mathrm{R}^{2}=0.64, \mathrm{p}<0.001\right)$. The combustion source was responsible for 45 $\%$ of the total PCDD/F concentrations in the segment from $\mathrm{km} 8.8$ to $\mathrm{km} 0.6$. Significant contributions from the probable chloranil source were observed in the river segment from $\mathrm{km} 8.8$ - $13.8(12-24 \%)$, at river $\mathrm{km} 5.0(14 \%)$ and at river $\mathrm{km} 1.8(23 \%)$ All the other locations showed comparable contributions (6.0 - 10\%). Contribution from PCB Aroclor mixtures were lower than the previous sources with higher values observed in the 
segment from river $\mathrm{km} 10.6$ to river $\mathrm{km} 5.0$ (13\% - $20 \%)$, which had elevated concentrations of PCBs in the sediments (Khairy and Lohmann, University of Rhode Island, Graduate School of Oceanography, Narragansett, RI, USA, unpublished data) and at river $\mathrm{km} 0.60(16 \%)$. The contamination with 2,3,7,8-TCDD from the historic DAP source was observed in the segment from $\mathrm{km} 16$ to $\mathrm{km} 0.6$ with comparable contributions $(5.0 \%-12 \%)$ of the total PCDD/Fs.

In terms of concentrations (Figure S4), the highest concentration corresponding to the mixed urban source was observed at river $\mathrm{km} 5.0$ (1300 pg/g dw), and comparable PCDD/F were observed at river km 29.8 (640 pg/g dw), river km 17.6 (728 pg/g dw), river $\mathrm{km} 16$ (842 pg/g dw), river $\mathrm{km} 10.6$ - 12.8 (842 - 947 pg/g dw), and river $\mathrm{km} 5.4$ 6.7 (811-877 pg/g dw), which were all higher than concentrations observed at all the other locations in the Passaic River. Accordingly, we conclude that PCDD/Fs released from this source are evenly distributed throughout the entire river (comparable level of activities at the sampling sites).

Concentrations of PCDD/Fs originating from the combustion source showed a similar pattern to the contribution levels, where concentrations generally increased from river $\mathrm{km} 12.8$ (300 pg/g dw) reaching its maximum at river $\mathrm{km} 5.0$ (2400 pg/g dw) followed by a decrease in the concentrations from river $\mathrm{km} 3.7$ (1017 pg/g dw) reaching its minimum concentration at river $\mathrm{km} 0.6(105 \mathrm{pg} / \mathrm{g} \mathrm{dw})$, which is similar to the trend observed for total PCDD/F concentrations in the sediments (Figure 2). This observed pattern is probably related to some existing activities such as the municipal waste 
incineration occurring at the Essex County Resource Recovery Facility and/or electric generating stations (Figure 1) near the Superfund site.

Higher sedimentary concentrations of PCDD/F originating from the probable chloranil signature occurred in the river segment from $\mathrm{km} 13.8$ - $1.8(147-838 \mathrm{pg} / \mathrm{g} \mathrm{dw})$ (Figure S4). which is probably related to discharges from combined sewer overflows (CSOs), where the majority of these CSO exist at the same river segment [53]. Additionally, NOAA [54] indicated that local industries such as, tanneries, textiles, paints and dyes still exist in the lower Passaic River. Surprisingly, the probable chloranil signature appeared in one sample above Dundee Dam (River km 28.8). However the sedimentary concentration corresponding to this source at this site ( $35 \mathrm{pg} / \mathrm{g} \mathrm{dw})$ is 4.0 24 folds lower than concentrations detected in the downriver sediments. The reason for the appearance of this fingerprint at this location is not clearly known. According to New Jersey Department of Environmental Protection (NJ-GeoWeb; http://njwebmap.state.nj.us/NJGeoWeb), no CSOs are located close to this location. However, there are $3 \mathrm{CSOs}$ located $2.8 \mathrm{kms}$ to the north of our sampling site. Additionally, several contaminated sites such as the former Garden State Paper Company Inc, Recycled Paperboard Inc are located close to our sampling site.

In Newark Bay, (Figure 1), sediments were dominated by PCDD/Fs originating from the probable mixed urban source $(54 \%)$ followed by chloranil $(20 \%)>$ combustion $(18 \%)>$ Diamond Alkali Plant and PCBs (5.0 \% each).

In terms of WHO-TEQ, the historic contamination from the former Diamond Alkali Plant was on average responsible for $60 \%$ of the total surficial sediment 
concentrations in the Lower Passaic River and Newark Bay, followed by combustion (21 $\%)$, PCBs (11\%), chloranil (6.0\%), and the mixed urban sources (2.0\%).

\section{Temporal trends of the identified sources}

Normalized source contributions in the previously reported core samples [6] together with the corresponding surficial sediment sample from the present study are shown in Figure 5. Predicted concentrations (pg/g dw) of all the probable sources in the Passaic River in 2007 and 2011 were lower than concentrations in 1976 and 1991 indicating a decrease in activities emitting PCDD/Fs in recent years (Supplemental Data, Table S3). Normalized concentrations of 2,3,7,8-TCDD (representing the aged DAP source) showed an exponential decay relationship $\left(R^{2}=0.99, p=0.002\right)$ where contributions (from the total PCDD/Fs) decreased annually by a rate of $7.0 \%$ from 1976 (93\%) to 2011 (9.0\%). Relative contributions from all the other four probable sources were higher in the recent years compared to 1976 and 1991 (Figure 4A). This is related to the great decline in the contribution of Diamond Alkali Plant (which was considered the major source of $\mathrm{PCDD} / \mathrm{Fs}$ in the region) in the upper layers, as compared to the lower layers) rather than an increase in PCDD/F emissions from the other sources (Table S3).

In Newark Bay, concentrations of PCDD/Fs corresponding to the extracted dioxin sources were always lower in 2011 (Table S3) compared to all the other layers which showed comparable concentrations except for the DAP source, where the maximum detected concentrations were observed in $1977(1,700 \mathrm{pg} / \mathrm{g} \mathrm{dw})$ and $1954(1,200 \mathrm{pg} / \mathrm{g}$ $\mathrm{dw}$ ), comprising $15 \%$ and $12 \%$ respectively of the total detected PCDD/F concentrations (Figure 4B). This agrees well with the operational period of the plant. In all the samples, 
the probable mixed urban sources showed the highest contribution, which were comparable in all the years (37\% - $47 \%)$ followed by combustion ( $26 \%$ - $32 \%)$, chloranil (7.0 - $17 \%)$, PCBs (5.0 $12 \%)$ and DAP (4.0 - $15 \%)$.

In terms of TEQ concentrations, it is clear that the DAP aged source is the major contributor to total PCDD/Fs in all years comprising on average $76 \%$ of the total TEQ concentrations for each of the Passaic River (Figure 5C) and Newark Bay (Figure 5D).

\section{Comparison to other studies in the Passaic River}

Wenning et al. [23] used principle component analysis to identify the sources of PCDD/Fs in sediments of the lower Passaic River and Newark Bay. Unfortunately, contributions of the identified sources were not provided. They indicated that several sources exist including PCBs, municipal solid waste incineration, smelting operations, wastewater sludge, wastewater effluents, penatchlorophenol (in Newark Bay only), pulp and paper mills, and contamination from the former DAP, which is in good agreement with our identified sources. However, pulp and paper mills fingerprint was not observed in any of the investigated sediments in the present study.

In the study of Ehrlich et al. [22], five sources were identified using the polytopic vector analysis including sewage sludge, pulp and paper mills, combustion, DAP and PCBs which is also in good agreement with our findings except for pulp and paper mills and sewage sludge. However for sewage sludge, their source profile showed high loadings on $1,2,3,4,6,7,8,9-\mathrm{CDD}$ and $1,2,3,4,6,7,8-\mathrm{CDD}$, which is similar to source factor 2 (mixed urban sources) in the present study (Supplemental Data, Table S4). 
Barabas et al. [25] identified 10 sources of PCDD/Fs + an additional dechlorination source in 94 sediment cores taken at 27 transects along the Passaic river using a modified polytopic vector analysis. OCDD data were not entered in their model. The identified sources include chloranil/PCP and dye production (20\%; present study: 13 $\%$ ), combustion (19\%; present study: $25 \%$ ), PCBs (13\%; present study: $8.0 \%), 2,4,5-\mathrm{T}$ production (12\%; present study: $13 \%$ ), atmospheric PCP (12\%; present study: $41 \%$ ). treated wastewater from vinyl chloride monomer/PVC production $(11 \%), 2,4-\mathrm{D}(4.0 \%)$, PVC waste $(2.0 \%)$ and an unknown source (4.0\%). Most of the sources were identified in the present study with close contribution levels except for the atmospheric PCP (mixed urban source in our study), which could be related to the $1,2,3,4,6,7,8,9-\mathrm{CDD}$ congener which was included in our study and was heavily loaded on this source.

\section{Risk assessment of $P C D D / F s$.}

Estimation of the uptake of PCDD/Fs by biota: Geometric means of predicted lipid concentrations compared to the measured lipid concentrations in pelagic $(n=3)$, benthopelagic $(n=6)$, benthic $(n=11)$ and blue crab samples $(n=2)$ are shown in Figures 5A, 5B, 5C and 5D respectively. LDPE - based river water and porewater concentrations were generally better predictors of PCDD/Fs in tissues of the pelagic and benthopelagic fish, whereas porewater and sediment $\mathrm{OC}+\mathrm{BC}$ were the best predictors in the benthic fish and blue crab samples (see SI for more details).

Friedman and Lohmann [55] indicated that porewater is the best predictor of PCDD/Fs in the tissue of clams (Mya arenaria) and deposit-feeding tube worms (Pectinaria gouldii) collected from the Passaic River and Newark Bay, which was in 
good agreement with our findings. Based on the obtained results, we can conclude that blue crabs and benthic fish bioaccumulate PCDD/Fs from the exposure to porewater and sediment (to a lesser extent), whereas the pelagic and benthopelagic fish, porewater and river water are the major sources of bioaccumulation. Khairy et al. [2] indicated that 2,3,7,8-TCDD, 1,2,3,7,8-PeCDF and 2,3,4,7,8-PeCDF undergo trophic magnification in the aquatic food web of the Passaic River and accordingly, dietary uptake is also considered an important source of these congeners in the fish species located at the higher trophic levels.

Bioaccumulation factors (BAFs) were calculated for blue crab and representatives of benthic (Anguilla rostrata), benthopelagic (Morone saxatilis) and pelagic (Dorosoma cepedianum) species based on porewater concentrations (Supplemental Data, Figure S5). A significant positive log-linear relationship between $\mathrm{K}_{\text {lip-w }}$ and BAFs of PCDD/Fs $\left(\mathrm{r}^{2}=\right.$ $0.82-0.89, \mathrm{p}<0.006)$ in all the investigated species indicating that equilibrium partitioning with the porewater water controls the bioaccumulation of PCDD/Fs in tissues.

Penta-through hexa-chlorinated dioxins/fiuran in the pelagic and benthopelagic fish, and mono- through tri-chlorinated dioxins/furans (lower chlorinated congeners) and hepta-through octa-chlorinated doxins/furans in the majority of the biota samples (including blue crabs) were overestimated by all the sorbents used (including the porewater). In contrast, the best prediction by porewater was for PCDD/F congeners with $\log \mathrm{K}_{\mathrm{OW}}$ values ranging from 6.33 to 7.94 . Several explanations are available for this observed pattern. The estimated lipid concentrations from the different sorbents does not 
consider the metabolic transformation of PCDD/Fs by the organisms, which we assume play an important role with the lower chlorinated PCDD/F congeners. Our recent work [2] indicated that the lower chlorinated PCDD/F congeners undergo significant trophic dilution in the aquatic food web of the Passaic River in contrast to PCB congeners with similar $\log \mathrm{K}_{\mathrm{OW}}$ values. This supports our assumption that metabolic transformation is the key factor leading to the observed, and overestimated, lipid concentrations. For the higher chlorinated PCDD/F congeners, our previous study [2] also indicated that these congeners might also undergo trophic dilution. Accordingly, metabolic transformation could partially be the reason for the observed overestimated lipid concentrations. Another explanation for the higher chlorinated congeners may be attributed to porewater sediment sorption - desorption kinetics.

Risk characterization of fish: The risk posed by PCDD/Fs in the fish species was estimated by applying the hazard quotient (HQ) approach. In the first approach (no effect concentration), two HQs were calculated (Supplemental Data, Table S5): $\mathrm{HQ}_{90 \%}$ which represent the level of risk that protects $90 \%$ of the exposed fish species and $\mathrm{HQ}_{99 \%}$ representing the level of risk protecting $99 \%$ of the fish species. As shown in Table S5, calculated $\mathrm{HQ}_{90 \%}$ and $\mathrm{HQ}_{99 \%}$ were all > 1 (except for $\mathrm{HQ}_{90 \%}$ calculated for Fundulus heteroclitus) indicating that adverse ecological effects are expected to occur with respect to the levels of PCDD/Fs detected in the tissues of the fish species.

Based on the trophic group, fish species were arranged in the following descending order: predator (Morone saxatilis, $\mathrm{HQ}_{90 \%}$ : 4.0; $\mathrm{HQ}_{99 \%}$ : 54) > carnivores (Morone americana, Fundulus diaphanus, Anguilla rostrata) and planktivores (Menidia menidia and Dorosoma cepedianum, $\mathrm{HQ}_{90 \%}$ : 3.0; $\mathrm{HQ}_{99 \%}$ : 41-53) > omnivores 
(Hybognathus regius and Fundulus heteroclitus, $\mathrm{HQ}_{90 \%}$ : 2.0; $\mathrm{HQ}_{99 \%}$ : 40). Based on the feeding strategy, benthic, benthopelagic and pelagic fish species showed close $\mathrm{HQ}_{90 \%}$ and $\mathrm{HQ}_{99 \%}$ values ranging from 3.0 - 4.0 and 37 - 47 respectively.

Calculated $\mathrm{HQ}_{90 \%}$ and $\mathrm{HQ}_{99 \%}$ significantly increased with the increase in the trophic level $\left(\mathrm{R}^{2}=0.52, \mathrm{SE}=0.52, \mathrm{p}<0.001\right)$, which is probably related to the difference in the ingested food items (i.e., biomagnification).

In the second approach, species specific tissue screening concentrations (TSC)] were calculated from porewater, river water and sediments (Supplemental Data, Table S6). These were compared to the detected tissue concentrations in the Passaic River using the HQ approach (Supplemental Data, Table S7). As shown in Table 1, calculated HQs based on river water and porewater concentrations were $>1$ for all the fish species (pelagic, benthopelagic and benthic fish) indicating the possibility of occurrence of adverse ecological effects from the exposure to porewater or the river water. Similarly, HQs based on the sediment concentrations were $>1$ in all the fish samples (assuming the possibility of exposure to sediments) and blue crab samples. Lastly, calculated HQs based on sediments were much greater than those based on freely dissolved concentrations, suggesting that benthic species, which are in direct contact with the contaminated sediments, could be affected more strongly than pelagic organisms (i.e. fish) from the exposure to $\mathrm{PCDD} / \mathrm{Fs}$.

Risk characterization of benthic species: Blue crab was the only sampled benthic invertebrate in the present study. Detected sediment concentrations in the present study were higher than the sediment quality guidelines for the protection of benthic species in 
$100 \%$ (low level risk) and $86 \%$ (high level risk) of the analyzed samples (Table 1).

Additionally, sedimentary concentrations were higher than the ESB (299 pg TEQ /g OC) in $91 \%$ of the samples, and the only samples that were below the guideline were located above the Dundee Dam (reference site). Accordingly, we conclude that adverse ecological effects are expected to occur in benthic species from the exposure to PCDD/Fs in sediments.

Calculated porewater toxic unit (PWTU) in the present study ranged from 0.22 6.50 , and values were $>1$ in $77 \%$ of the samples indicating that the exposure to $\mathrm{PCDD} / \mathrm{Fs}$ in sediments and/or porewater could possibly result in the occurrence of adverse ecological effects to benthic species.

\section{CONCLUSION}

The present study was performed to determine concentrations, sources and perform a risk assessment of PCDD/Fs in surficial sediments of the lower Passaic River and Newark Bay. The USEPA PMF model identified five source factors, four of which closely matched literature profiles including chloranil, combustion, PCBs and mixed urban sources, plus another factor, which was assigned to represent emissions from the DAP. Our identified probable sources were in good agreement to sources that were previously identified for the region. However, we did not detect other sources such as pulp and paper bleach and recycled paper and pulp mill effluents that were previously identified as major sources in the region. The DAP historic source (mainly 2,3,7,8TCDD) had only minor contributions to the total PCDD/F concentrations in the surficial sediments $(0.0 \%-12 \%)$. However, it is responsible on average for $60 \%$ of the total 
TEQ concentrations in surficial sediments. This source fingerprint was observed not only in the sediments corresponding to the former DAP (river km 5.0), but was also observed upstream until river km 16 and downstream in Newark Bay. Accordingly we conclude that this historic source is still spatially conserved in sediments and that it is the major source of toxicity in the sediments. Our results also indicated that although there was a great decline in the detected concentrations of PCDD/Fs in the Passaic River (Table A3) (concentrations in the deep sediments corresponding to 1976 were 60 times higher than concentrations in the surficial sediments), detected concentrations still pose a great risk to humans, fish and benthic organisms exposed to the sediments and porewater. Several lines of evidence were used to assess the ecological risk from the exposure to PCDD/Fs from water, porewater and sediments including tissue no effect concentrations (using two protection thresholds), tissue screening concentrations, porewater toxic unit, comparison with published SQGs for the protection of benthic species and fish and assessment of the bioaccumulation and biomagnification potential of PCDD/Fs. All the used approaches indicated the existence of great risk from the exposure of fish and benthic species to $\mathrm{PCDD} /$ Fs. Additionally, PCDD/Fs were found to bioaccumulate and biomagnify in the aquatic food web of the Passaic River [2]. We also indicated that PCDD/Fs bioaccumulate in the fish and blue crab from sediments (particularly for 2,3,7,8-TCDD) and porewater (for the majority of PCDD/F congeners). Accordingly, we conclude that PCDD/Fs are still contaminants of potential concern in the Passaic River. To further reduce the uncertainty associated with the used risk estimation approaches in this preliminary risk assessment, experimental effect evidences such as site specific cellularstress biomarkers and toxicity bioassay should be evaluated in a weight-of-evidence 
procedure. Additionally, to further reduce concentration $\mathrm{PCDD} / \mathrm{Fs}$ in surficial sediments,

emissions from the major ongoing sources, revealed in the present study must be reduced.

\section{ACKNOWLEDGMENT}

We acknowledge funding from the Hudson River Foundation (Hudson River Award \# HRF 2011-5) and SERDP (ER-2538). We thank Dave Adelman (URI) and Paul Lerin for collection of the sediment samples.

\section{REFERENCES}

[1] Iannuzzi TJ, Ludwig DF. 2004. Historical and current ecology of the lower Passaic River. Urban Habitats 2:147-173.

[2] Khairy MA, Weinstein MP, Lohmann R. 2014. Trophodynamic Behavior of Hydrophobic Organic Contaminants in the Aquatic Food Web of a Tidal River. Environmental Science \& Technology 48:12533-12542.

[3] Munoz GR, Panero MA, Consortium NYNJH. 2006. Pollution prevention and management strategies for dioxins in the New York/New Jersey Harbor. New York Academy of Sciences.

[4] Bopp RF, Gross ML, Tong H, Simpson HJ, Monson SJ, Deck BL, Moser FC. 1991. A major incident of dioxin contamination: sediments of New Jersey estuaries. Environmental Science \& Technology 25:951-956.

[5] USEPA. 2014. Focused Feasibility Study Report for the Lower Eight Miles of the Lower Passaic River. U.S. Environmental Protection Agency, Region 2. New York, NY.

[6] Lambert MK, Friedman C, Luey P, Lohmann R. 2011. Role of Black Carbon in the Sorption of Polychlorinated Dibenzo-p-dioxins and Dibenzofurans at the Diamond Alkali Superfund Site, Newark Bay, New Jersey. Environmental Science \& Technology 45:4331-4338.

[7] Fernandez MP, Ikonomou MG, Courtenay SC, Wirgin II. 2004. Spatial Variation in Hepatic Levels and Patterns of PCBs and PCDD/Fs among Young-of-the-Year and Adult Atlantic Tomcod (Microgadus tomcod) in the Hudson River Estuary. Environmental Science \& Technology 38:976-983.

[8] Sundqvist KL, Tysklind M, Geladi P, Hopke PK, Wiberg K. 2010. PCDD/F Source Apportionment in the Baltic Sea Using Positive Matrix Factorization. Environmental Science \& Technology 44:1690-1697.

[9] Sofowote UM, McCarry BE, Marvin CH. 2008. Source Apportionment of PAH in Hamilton Harbour Suspended Sediments: Comparison of Two Factor Analysis Methods. Environmental Science \& Technology 42:6007-6014.

[10] Khairy MA, Lohmann R. 2013. Source apportionment and risk assessment of polycyclic aromatic hydrocarbons in the atmospheric environment of Alexandria, Egypt. Chemosphere 91:895-903. 
[11] Gedik K, Demircioğlu F, İmamoğlu İ. 2010. Spatial distribution and source apportionment of PCBs in sediments around İzmit industrial complexes, Turkey. Chemosphere 81:992-999.

[12] Imamoglu I, Christensen ER. 2002. PCB sources, transformations, and contributions in recent Fox River, Wisconsin sediments determined from receptor modeling. Water Research 36:3449-3462.

[13] Hosomi M, Matsuo T, Dobashi S, Katou S, Abe H. 2003. Survey of dioxins in Tokyo Bay bottom sediment. Marine Pollution Bulletin 47:68-73.

[14] Sundqvist KL, Tysklind M, Geladi P, Cato I, Wiberg K. 2009. Congener fingerprints of tetra- through octa-chlorinated dibenzo-p-dioxins and dibenzofurans in Baltic surface sediments and their relations to potential sources. Chemosphere 77:612620.

[15] Masunaga S, Yao Y, Ogura I, Nakai S, Kanai Y, Yamamuro M, Nakanishi J. 2001. Identifying Sources and Mass Balance of Dioxin Pollution in Lake Shinji Basin, Japan. Environmental Science \& Technology 35:1967-1973.

[16] Fiedler H, Lau C, Kjeller LO, Rappe C. 1996. Patterns and sources of polychlorinated dibenzo-p-dioxins and dibenzofurans found in soil and sediment samples in Southern Mississippi. Chemosphere 32:421-432.

[17] Birch GF, Harrington C, Symons RK, Hunt JW. 2007. The source and distribution of polychlorinated dibenzo-p-dioxin and polychlorinated dibenzofurans in sediments of Port Jackson, Australia. Marine Pollution Bulletin 54:295-308.

[18] Bonn BA. 1998. Polychlorinated Dibenzo-p-dioxin and Dibenzofuran Concentration Profiles in Sediment and Fish Tissue of the Willamette Basin, Oregon. Environmental Science \& Technology 32:729-735.

[19] Sakurai T, Suzuki N, Masunaga S, Nakanishi J. 1998. Origin attribution of polychlorinated dibenzo p-dioxins and dibenzofurans in sediment and soil from a Japanese freshwater lake area through congener-specific data analysis. Chemosphere 37:2211-2224.

[20] Assefa AT, Tysklind M, Sobek A, Sundqvist KL, Geladi P, Wiberg K. 2014. Assessment of PCDD/F Source Contributions in Baltic Sea Sediment Core Records. Environmental Science \& Technology 48:9531-9539.

[21] Uchimiya M, Masunaga S. 2007. Time Trends in Sources and Dechlorination Pathways of Dioxins in Agrochemically Contaminated Sediments. Environmental Science \& Technology 41:2703-2710.

[22] Ehrlich R, Wenning RJ, Johnson GW, Su SH, Paustenbach DJ. 1994. A mixing model for polychlorinated dibenzo-p-dioxins and dibenzofurans in surface sediments from Newark Bay, New Jersey using polytopic vector analysis. Arch Environ Contam Toxicol 27:486-500.

[23] Wenning R, Harris M, Ungs M, Paustenbach D, Bedbury H. 1992. Chemometric comparisons of polychlorinated dibenzo-p-dioxin and dibenzofuran residues in surficial sediments from Newark Bay, New Jersey and other industrialized waterways. Arch Environ Contam Toxicol 22:397-413.

[24] Wenning R, Paustenbach D, Harris M, Bedbury H. 1993. Principal components analysis of potential sources of polychlorinated dibenzop-dioxin and dibenzofuran residues in surficial sediments from Newark Bay, New Jersey. Arch Environ Contam Toxicol 24:271-289. 
[25] Barabás N, Goovaerts P, Adriaens P. 2004. Modified polytopic vector analysis to identify and quantify a dioxin dechlorination signature in sediments. 2. Application to the Passaic River. Environmental science \& technology 38:1821-1827.

[26] Hopke PK. 2003. Recent developments in receptor modeling. Journal of Chemometrics 17:255-265.

[27] Aydin YM, Kara M, Dumanoglu Y, Odabasi M, Elbir T. 2014. Source apportionment of polycyclic aromatic hydrocarbons (PAHs) and polychlorinated biphenyls (PCBs) in ambient air of an industrial region in Turkey. Atmospheric Environment 97:271-285.

[28] Rodenburg LA, Du S, Xiao B, Fennell DE. 2011. Source apportionment of polychlorinated biphenyls in the New York/New Jersey Harbor. Chemosphere 83:792798.

[29] USEPA. 2006. An Inventory of Sources and Environmental Releases of DioxinLike Compounds in the United States for the Years 1987, 1995, and 2000. National Center for Environmental Assessment, Office of Research and Development, U.S. Environmental Protection Agency, Washington, DC 20460.

[30] USEPA. 1998. Guidelines for Ecological Risk Assessment. EPA/630/R-95/002F. Final Report.Washington, DC.

[31] Burgess RM, Berry WJ, Mount DR, Di Toro DM. 2013. Mechanistic sediment quality guidelines based on contaminant bioavailability: Equilibrium partitioning sediment benchmarks. Environmental Toxicology and Chemistry 32:102-114.

[32] Burgess RM, Driscoll SBK, Maynard M, Ozretich RJ, Mount DR, Reiley MC. 2012. Equilibrium Partitioning Sediment Benchmarks (ESBS) for the Protection of Benthic Organisms: Procedures for the Determination of the Freely Dissolved Interstitial Water Concentrations of Nonionic Organics.

[33] CCME. 2001. Canadian sediment quality guidelines for the protection of aquatic life: Polychlorinated dibenzo- $p$-dioxins and polychlorinated dibenzofurans. Canadian Council of Ministers of the Environment.

[34] Cook P. 1993. Interim report on data and methods for assessment of 2, 3, 7, 8tetrachlorodibenzo-p-dioxin risks to aquatic life and associated wildlife.

[35] MPCA. 2014. Human Health-based Water Quality Standards Technical Support Document. Water Quality Standard Amendments - Minn. R. chs. 7050 and 7052.

[36] NYWQSGV. 1988. Ambient water quality standards and guidance values and groundwater effluebt limitations.

[37] Steevens JA, Reiss MR, Pawlisz AV. 2005. A methodology for deriving tissue residue benchmarks for aquatic biota: A case study for fish exposed to 2, 3, 7, 8tetrachlorodibenzo-p-dioxin and equivalents. Integrated environmental assessment and management 1:142-151.

[38] Eitzer BD. 1993. Comparison of point and nonpoint sources of polychlorinated dibenzo-p-dioxins and polychlorinated dibenzofurans to sediments of the Housatonic River. Environmental Science \& Technology 27:1632-1637.

[39] Rose CL, McKay WA, Ambidge PF. 1994. PCDD and PCDF levels in river systems in England and Wales, UK. Chemosphere 29:1279-1292.

[40] Sakurai T, Kim J-G, Suzuki N, Matsuo T, Li D-Q, Yao Y, Masunaga S, Nakanishi J. 2000. Polychlorinated dibenzo-p-dioxins and dibenzofurans in sediment, 
soil, fish, shellfish and crab samples from Tokyo Bay area, Japan. Chemosphere 40:627640.

[41] Bellucci LG, Frignani M, Raccanelli S, Carraro C. 2000. Polychlorinated Dibenzo-p-dioxins and Dibenzofurans in Surficial Sediments of the Venice Lagoon (Italy). Marine Pollution Bulletin 40:65-76.

[42] Sundqvist K, Tysklind M, Cato I, Bignert A, Wiberg K. 2009. Levels and homologue profiles of PCDD/Fs in sediments along the Swedish coast of the Baltic Sea. Environ Sci Pollut Res 16:396-409.

[43] CARP. 2008. Environmental data.

[44] Quadrini JD, Ku W, Connolly JP, Chiavelli DA, Israelsson PH. 2015. Fingerprinting 2,3,7,8-tetrachlorodibenzodioxin contamination within the lower Passaic River. Environmental Toxicology and Chemistry 34:1485-1498.

[45] Koh CH, Khim JS, Kannan K, Villeneuve DL, Senthilkumar K, Giesy JP. 2004. Polychlorinated dibenzo-p-dioxins (PCDDs), dibenzofurans (PCDFs), biphenyls (PCBs), and polycyclic aromatic hydrocarbons (PAHs) and 2,3,7,8-TCDD equivalents (TEQs) in sediment from the Hyeongsan River, Korea. Environmental Pollution 132:489-501.

[46] Friedman CL, Cantwell MG, Lohmann R. 2012. Passive sampling provides evidence for Newark Bay as a source of polychlorinated dibenzo-p-dioxins and furans to the New York/New Jersey, USA, atmosphere. Environmental Toxicology and Chemistry 31:253-261.

[47] Quadrini JD, $\mathrm{Ku} \mathrm{W,} \mathrm{Connolly} \mathrm{JP,} \mathrm{Chiavelli} \mathrm{DA,} \mathrm{Israelsson} \mathrm{PH.} 2015$. Fingerprinting 2,3,7,8-tetrachlorodibenzodioxin contamination within the lower Passaic River. Environmental Toxicology and Chemistry:n/a-n/a.

[48] Sundqvist KL, Tysklind M, Geladi P, Hopke P, Wiberg K. 2010. PCDD/F source apportionment in the Baltic Sea using positive matrix factorization. Environmental science \& technology 44:1690-1697.

[49] Tian F, Chen J, Qiao X, Cai X, Yang P, Wang Z, Wang D. 2008. Source identification of PCDD/Fs and PCBs in pine (Cedrus deodara) needles: A case study in Dalian, China. Atmospheric Environment 42:4769-4777.

[50] Hilscherova K, Kannan K, Nakata H, Hanari N, Yamashita N, Bradley PW, McCabe JM, Taylor AB, Giesy JP. 2003. Polychlorinated Dibenzo-p-dioxin and Dibenzofuran Concentration Profiles in Sediments and Flood-Plain Soils of the Tittabawassee River, Michigan. Environmental Science \& Technology 37:468-474.

[51] Chang MB, Chang SH, Chen YW, Hsu HC. 2004. Dioxin emission factors for automobiles from tunnel air sampling in Northern Taiwan. Science of the total environment 325:129-138.

[52] Lee W-S, Chang-Chien G-P, Wang L-C, Lee W-J, Tsai P-J, Wu K-Y, Lin C. 2004. Source identification of PCDD/Fs for various atmospheric environments in a highly industrialized city. Environmental science \& technology 38:4937-4944.

[53] Huntley S, Iannuzzi T, Avantaggio J, Carlson-Lynch H, Schmidt C, Finley B. 1997. Combined sewer overflows (CSOs) as sources of sediment contamination in the lower Passaic River, New Jersey. II. Polychlorinated dibenzo-p-dioxins, polychlorinated dibenzofurans, and polychlorinated biphenyls. Chemosphere 34:233-250.

[54] NOAA. 2007. Diamnod Alkali superfund site. Natural resource damage assessment plan. 
[55] Friedman CL, Lohmann R. 2014. Comparing sediment equilibrium partitioning and passive sampling techniques to estimate benthic biota $\mathrm{PCDD} / \mathrm{F}$ concentrations in Newark Bay, New Jersey (U.S.A.). Environmental Pollution 186:172-179.

\section{Figures legend}

Figure 1: Map showing the sampling sites, 2011, contributions of PCDD/F sources in surficial sediments determined from the PMF model at each site and the possible sources in the region. DAP: Diamond Alkali pesticide manufacturing plant; ARI: Advanced Metal Recovery Incorporation; KSR: Kearny Smelting and Refining; MSM: Matonis Scrap Metal Inc.; ECRRF: Essex County Resource Recovery; EPG: Essex Power Generation Station; KPG: Kearny Power Generation Station; HPG: Hudson Power Generation Station; NB: Newark Bay.

Figure 2: Congener-based profiles of PCDD/Fs in pg/g dw (A) and pg TEQ/g dw (B) in 2011 surficial sediments.

Figure 3: Source profiles of PCDD/Fs (A-E) in the lower Passaic River extracted from the PMF model. PCP: pentachlorophenol; MSWI: municipal solid waste incineration; CFPP: coal fired power plants

Figure 4: Relative concentrations of the identified probable sources in sediment dated to indicated years in the lower Passaic River near km 5.0 (A, C) and Newark Bay (B, D). 
Figure 5: Ratios of estimated versus measured lipid-normalized PCDD/F biota concentrations. Biota concentrations were estimated based on $\mathrm{PCDD} / \mathrm{F}$ partitioning between biota and sediment organic carbon (OC), sediment OC and black carbon $(\mathrm{BC})$, polyethylene (PE) in porewater, and $\mathrm{PE}$ in river water for (a) pelagic, (b) benthopelagic, (c) benthic and (d) blue crab samples. 